\title{
Testis and Vas Deferens Morphology of the Red-clawed Mangrove Tree Crab (Goniopsis cruentata) (Latreille, 1803)
}

\author{
Tatiane Martins Garcia ${ }^{1}$ and José Roberto Feitosa Silva ${ }^{1,2 *}$ \\ ${ }^{1}$ Institut of Sea Sciences - LABOMAR; ${ }^{2}$ Biology Department; Federal of Ceara University; Av. Mister Hull, 2977; \\ Campus do Pici; Bloco 909; Laboratory of Animal Histology; 60455-760; robfeitosa@terra.com.br; Fortaleza - \\ Ceara-Brazil
}

\begin{abstract}
The present study describes the structure of the testes and vas deferens of the red-clawed mangrove tree crab, Goniopsis cruentata. Testes and vas deferens were fixed with cold Bouin's solution and submitted to histological routine examinations. Light microscopy showed the testis to be divided into three regions: anterior, containing the germinal zone; intermediary, including the collecting duct; and posterior. The vas deferens, which was continuous with the testes, could be divided into two regions: one corresponding to the expansions and another lined by cubical epithelium, collagenous fibers and a circular layer of muscle cells and containing the androgenic gland. Spermatophores were observed in both vas deferens regions suggesting that they participated in the maturation of the spermatozoids preparing the male functionally for fertilization.
\end{abstract}

Key words: Brachyura, Goniopsis cruentata, reproduction, spermatophore, testis, vas deferens

\section{INTRODUCTION}

The male reproductive organs of the malacostracans, including the decapods, are found in the cephalothorax or thorax (Krol et al., 1992). In decapods, the male reproductive tract consists of paired testes and genital ducts. Each genital duct consists of a collecting tube, a vas deferens with regionally distinct functions, and an ejaculatory duct ending in a seminal vesicle or in a terminal ampoule, depending on the species (Krol et al., 1992). When spermatogenesis is complete, the sexual cells are transported to the vas deferens (Hinsh and Walker, 1974). The vas deferens is a tubular duct (Krol et al., 1992) in which the sperm cells become encapsulated forming spermatophores (Hinsch and Mcknight, 1988;
Sainte-Marie and Sainte-Marie, 1999; Spalding, 1942).

Although much has been described on testis and vas deferens morphology, only few studies have dealt with crabs. The latter include light microscopy studies of the species Menippe mercenaria (Binford, 1913), Pachygrapsus marmoratus (Mouchet, 1931), Callinectes sapidus (Cronin, 1947; Johnson, 1980), Portunus sanguinolentus (Ryan, 1967), Libinia emarginata (Hinsh and Walker, 1974), Chionoecetes opilio (Beninger et al., 1988; Sainte-Marie and SainteMarie, 1999; Benhalima and Moriyasu, 2000) and Ucides cordatus (Leite, 2002). Testis and vas deferens morphology has been described for several other species of crustaceans, including Panulirus (Talbot and Summers, 1978), Scyllarus chacei (Hinsch and Mcknight, 1988), Thenus

\footnotetext{
${ }^{*}$ Author for correspondence
} 
orientalis (Burton, 1995), Panulirus laevicauda (Lima, 1995) and Diogenes pugilator (ManjónCabeza and Raso, 2000).

Spermatophore formation has been studied for a number of crustaceans using light microscopy, including the crab species C. sapidus (Cronin, 1947; Johnson, 1980), Portunus pelagicus (ElSherief, 1991), Scylla serrata (Uma and Subramoniam, 1979), Carcinus maenas (Spalding, 1942), P. marmoratus (Mouchet, 1931), Lithodes maja (Tudge et al., 1998), C. opilio (Beninger et al., 1988), U. cordatus (Leite, 2002), the lobster species P. laevicauda (Lima, 1995) and the hermit crab species D. pugilator (Manjón-Cabeza and Raso, 2000).

The present study studied the testis and vas deferens morphology and spermatophore formation of the red-clawed mangrove tree crab, Goniopsis cruentata (Latreille, 1803), in order to understand the reproductive process of this economically important fishing resource in Northeastern Brazil.

\section{MATERIALS AND METHODS}

Ten male specimens of $G$. cruentata were collected monthly from the mangrove of the Ceará River (Northeastern Brazil) between October 2002 and March 2003. Lifting the dorsal carapace and exposing the internal organs the testes and vas deferens were excised and fixed with cold Bouin's solution. After immersion in 70\% ethanol, segments of the organs were paraffin-embedded and cut serially in 5- $\mu \mathrm{m}$ sections. The sections were mounted and stained with Alcian Blue (adapted from Junqueira and Junqueira, 1983), Xylidine Ponceau (Pearse, 1960), PAS (adapted from Junqueira and Junqueira, 1983), Gomori Trichrome (adapted from Tolosa et al., 2003) and Mallory Trichrome (adapted from Tolosa et al., 2003).

\section{RESULTS}

\section{Testis}

The male reproductive organ of $G$. cruentata consisted of two basic components: a) the testes-a paired, H-shaped organ just beneath the dorsal carapace (Fig.1), and b) the relatively shorter vas deferens-a duct communicating with the outside through small papillae at the base of the last thoracic appendage. The testes are flat and highly coiled anteriorly, above the hepatopancreas and below the cardiac stomach. A commissure bridged the left and right testes at this point. Along the intestine and below the heart the testes became whiter, thicker and less coiled. The testis could be divided into three histologically distinct regions, in accordance with morphological variations in sexual cells and epithelium. The anterior, coiled region of the testis contains the germinal zone. It was lined externally by simple squamous epithelium contained sexual cells at different stages of maturation.

These cells were organized in groups called testicular cysts (Fig. 2A).

The intermediate region consisted of a collecting duct-covered by a simple columnar epithelium secreting a homogeneous polysaccharide, as evidenced by positive reactions to staining with Alcian Blue-and sexual cells which appeared to be in the same stage of maturation. The posterior region of the testis, which connected to the vas deferens (Fig. 2B), was lined with simple squamous epithelium and contain sexual cells in the same stage of maturation.

The entire testis was enveloped by a fibrous layer overlying the epithelium. Positive reactions to staining with Gomori Trichrome show this layer to be made of collagen (Fig. 2C-D).

\section{Vas deferens}

The sections of the vas deferens (Fig. 1) showed two distinct regions: One, corresponding to the expansions, was characterized by the presence of rod-shaped glycoprotein and polysaccharide depositions, as evidenced by positive reactions to staining with PAS and Alcian Blue, respectively (Fig. 3A). Transitions in epithelium characteristics revealed three distinct zones of the expansions: the epithelium was squamous proximally and distally and columnar in the intermediate region, forming a deep blind.

The intermediate region of the vas deferens was lined internally with simple cubic epithelium. The lumen was filled with rod-like polysaccharide and glycoprotein chains accompanying the structure observed in the expansion. Reinforced by a large amount of collagenous fibers, the basal membrane and epithelium were covered by a thick layer of muscle cells and groupings of epithelial cells. 


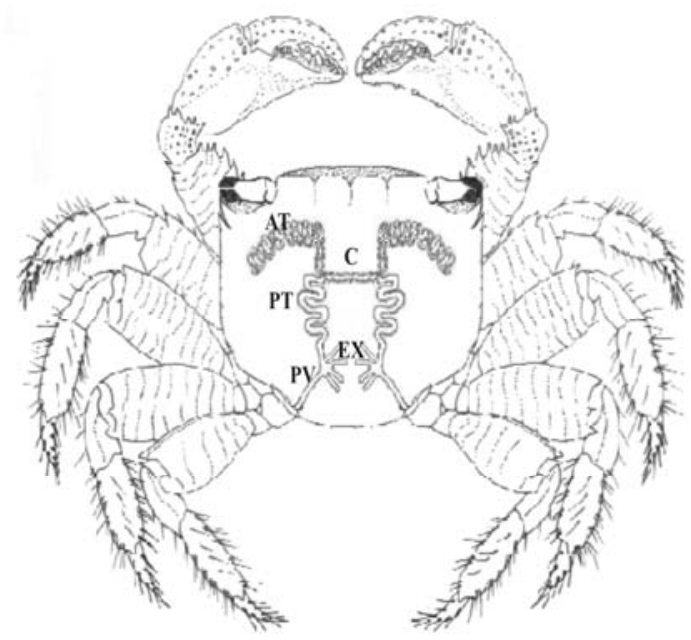

Figure 1 - Outline of the male reproductive system of Goniopsis cruentata. Anterior testis (AT) joined by a commissure (C), posterior testis (PT), Expansions (EX) and posterior vas deferens (PV)
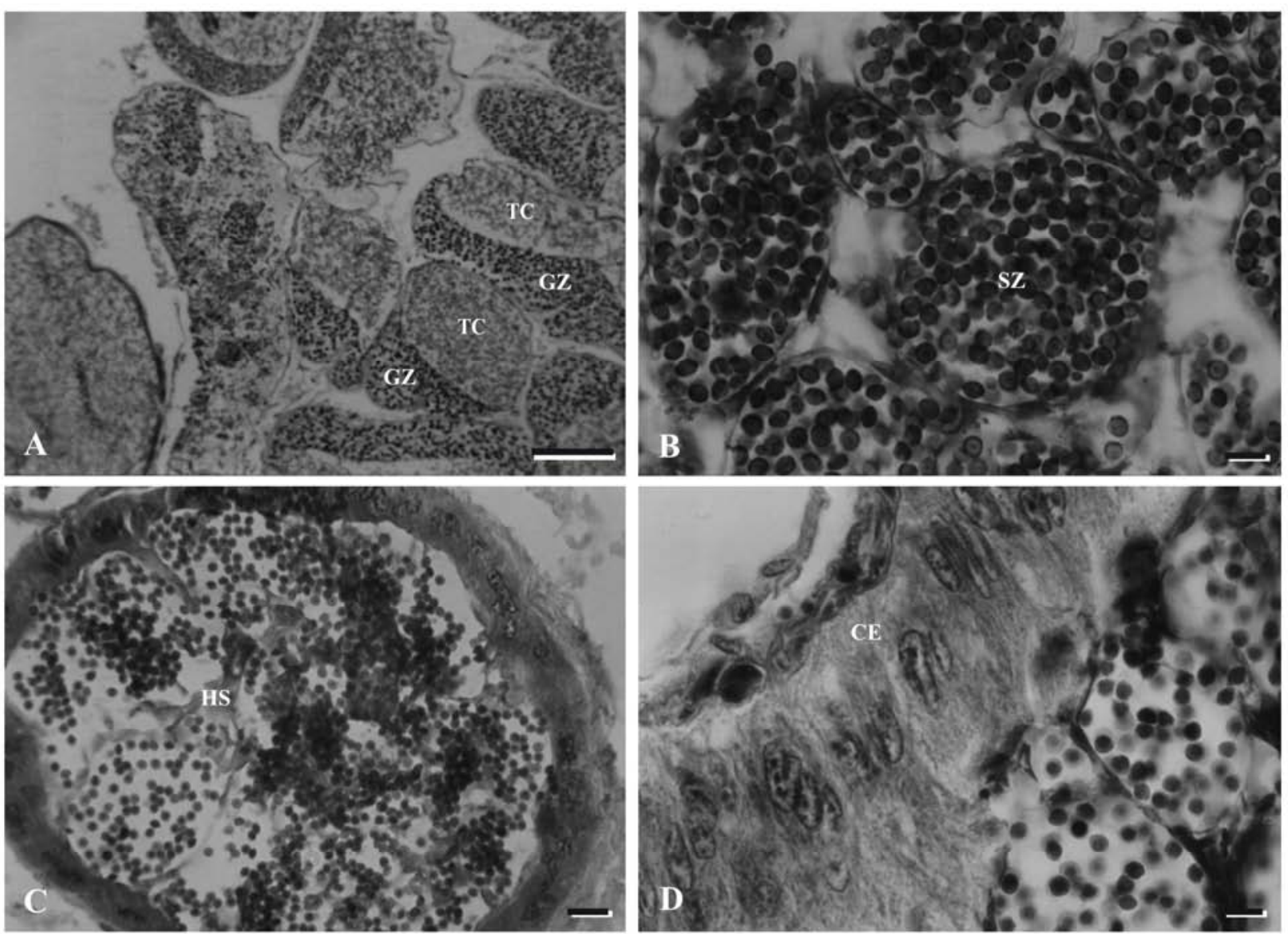

Figure 2 - Photomicrographs of the testis of Goniopsis cruentata. 2A: Anterior part of the testis showing germinal zone (GZ) and testicular cysts (TC): PAS (scale bar: $100 \mu \mathrm{m}$ ). 2B: Posterior region of the testis showing spermatozoa (SZ): Mallory Trichrome (scale bar: $10 \mu \mathrm{m}$ ). $2 \mathrm{C}$ : Homogeneous secretion (HS), stained with Gomori Trichrome (scale bar: $10 \mu \mathrm{m}$ ). 2D: Columnar epithelium (CE): Mallory Trichrome (scale bar: $10 \mu \mathrm{m}$ ). 

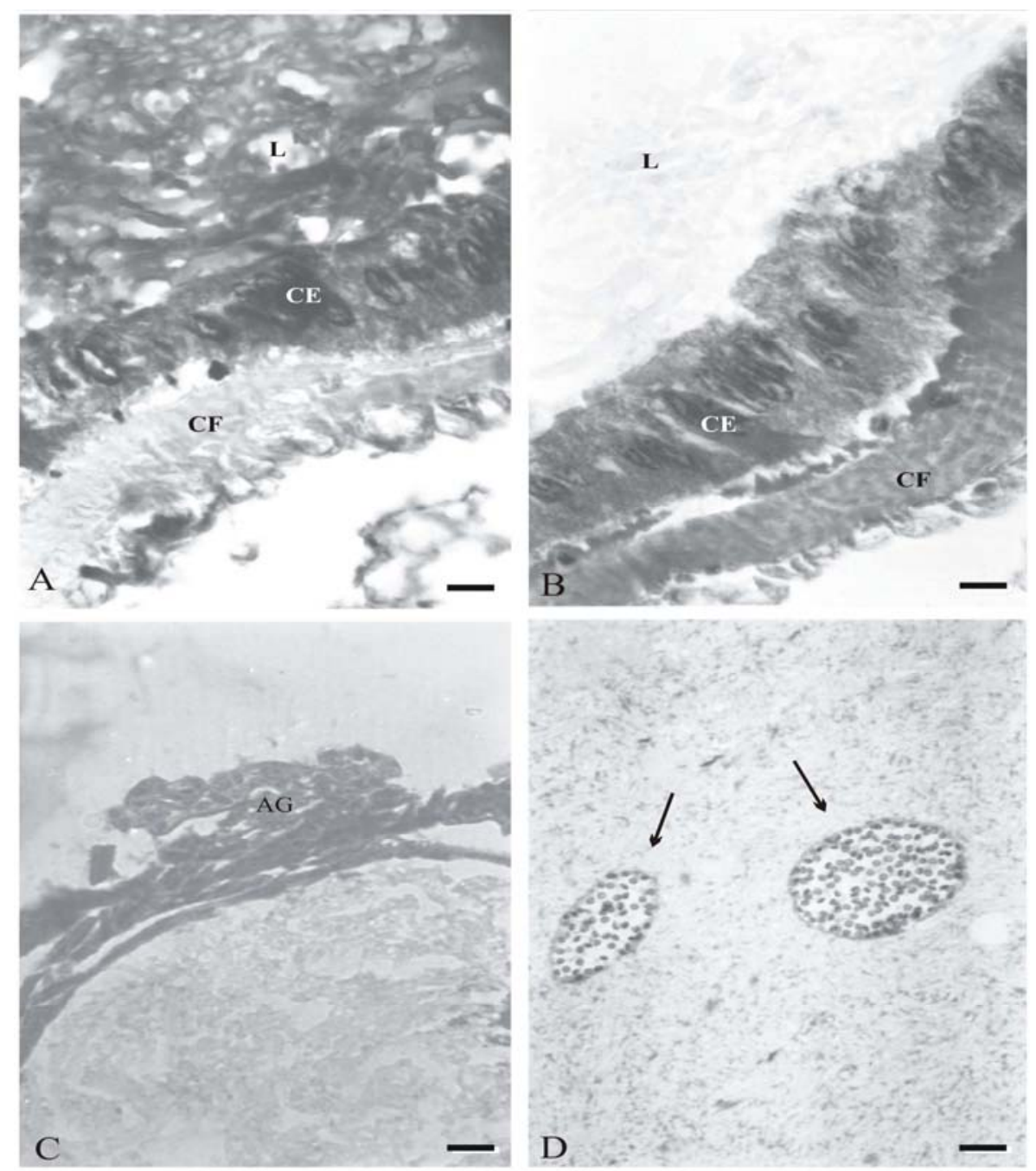

Figure 3 - Photomicrographs of the expansions of the male reproductive system of Goniopsis cruentata. 3A: lumen (L) filled with rod-like polysaccharide and glycoprotein chains. Simple columnar epithelium (CE) and collagenous fibers (CF): Alcian Blue/PAS (scale bar: 10 $\mu \mathrm{m}$ ). 3B: Simple columnar epithelium (CE), Lumen (L) and collagenous fibers (CF): Gomori Trichrome (scale bar: $10 \mu \mathrm{m})$. 3C: Androgenic gland (AG), stained with Xylidine Ponceau (scale bar: $20 \mu \mathrm{m}$ ). 3D: Spermatophores enveloped by a PAS- positive film: PAS (scale bar: $10 \mu \mathrm{m}$ ).

The epithelium became columnar in the vicinity of the gonopores. The semen was discharged through a small papillae at the base of the last thoracic leg.

\section{Spermatophore}

The sexual cells in the posterior part of the vas deferens and inside the expansions were enveloped by a PAS-positive film, forming a capsule called spermatophore (Fig. 3C-D). Spermatophores in the vas deferens could be oval or spherical.

\section{DISCUSSION}

\section{Testis}

The layout of the reproductive system of Goniopsis cruentata-i.e., the paired testes and vas deferens-was similar to reproductive systems described for decapods in general (Krol et al., 1992). These description of the testes and commissure of G. cruentata matched descriptions of Mouchet (1931), Ryan (1967), Johnson (1980), Burton (1995) and Lima (1995) for three crab species ( $P$. marmoratus, $P$. sanguinolentus and $C$. 
sapidus, respectively) and two lobster species ( $T$. orientalis and $P$. laevicauda, respectively). Incidentally, Leite (2002) did not report the existence of a commissure between the testes of $U$. cordatus.

The fibrous collagen layer observed in $G$. cruentata was similar to structures observed by Cronin (1947) and Johnson (1980) in the blue crab (C. sapidus), by Lima (1995) in the spiny lobster (P. laevicauda) and by Leite (2002) in the mangrove crab (U. cordatus). According to Cronin (1947), the testes of the blue crab were lined by a layer of epithelium and a layer of connective fibers. This finding was later confirmed by Johnson (1980), who referred to this connective tissue as the "fibrous capsule". In a discussion on similar structures in P. laevicauda, Lima (1995) refered to the fibrous layer as being collagenous. Leite (2002) reported the external layer of the testis of $U$. cordatus to be of fibrous nature.

Several authors observed cell groupings in the posterior part of the testes referring to them as either "lobes" (Ryan, 1967, for P. sanguinolentus; Johnson, 1980, for C. sapidus; Manjón-Cabeza and Raso, 2000, for D. pugilator), "tubules" (Binford, 1913, for M. mercenaria), "acines" (Burton, 1995, for T. orientalis) or "testicular cysts" (Leite, 2002, for U. cordatus). Burton (1995) showed that the external surface of the testes in $T$. orientalis consisted of simple squamous epithelium and collecting tubules lined with simple columnar epithelium. This matched the findings of the present study.

\section{Vas deferens}

The expansions of the vas deferens in G. cruentata displayed secretory activity. Mouchet (1931) observed similar activity in the vas deferens of the crab species $P$. marmoratus, as did Bauchau (1966) and Leite (2002) for the species C. maenas and $U$. cordatus, respectively. In the present study the vas deferens was considered as consisting of two major parts, although this was not always the case: the vas deferens of L. emarginata (Hinsch and Walker, 1974), C. sapidus (Johnson, 1980) and T. orientalis (Burton (1995) was divided into three parts, that of $S$. chacei (Hinsch and Mcknight, 1988) into four parts and that of $D$. pugilator (Manjón-Cabeza and Evenness, 2000) into as many as eight parts. Different criteria and different microscopic and macroscopic foci may account for this diversity.
The secretion from the expansions in G. cruentata consisted of rod-shaped glycoprotein and polysaccharide chains apparently originated in the columnar epithelium. In the posterior part of the vas deferens two substances could be observed, one of which was produced in the expansions while the other seems to be produced in the intermediate testis region. These secretions could play a role in spermatophore formation and were likely to correspond to the two amorphous substances mentioned by Sainte-Marie and SainteMarie (1999) in a study on the crab species $C$. opilio. These results suggested the finding of Beninger et al. (1988) who reported the existence of two different types of seminal fluid posteriorly in the vas deferens. However, Benhalima and Moriyasu (2000) reported that both fluids originated in the intermediate region of the vas deferens and underwent changes in chemical structure while passing to the posterior part of the vas deferens.

According to Mouchet (1931), the secretion produced in the expansions contains clusters of long, translucent and rod-like bodied. It could be observed as a flocculent substance enveloping the sexual cells (Hinsch and Mcknight, 1988) and testing positive for PAS (Talbot and Summers, 1978). According to Hinsh and Walker (1974), sperm maturation, spermatophore formation and seminal fluid production and storage all took place in the vas deferens of crustaceans. Burton (1995) found that the vas deferens stored spermatozoa from the testes for maturation and nourishment before ejaculating them.

In 1913, Binford described the vas deferens as a rectilinear structure lined with columnar epithelium secreting the substances required to produce the wall of the spermatophore. Cronin (1947) observed that most of the anterior part of the vas deferens was involved in the secretion of substances required to envelop and storing spermatophores. Hinsch and Mcknight (1988) also attributed early spermatophore formation and seminal fluid production to this region. However, Sainte-Marie and Sainte-Marie (1999) did not consider sperm cells leaving the testes and entering the vas deferens to be fully developed spermatozoa, but suggested these cells completed their maturation inside the spermatheca. Accordingly, the appropriateness of the term "vas deferens" was questioned and was suggested reconsidering its use for brachyuran crustaceans. 
Brachyuran spermatophores differ from those of Anomurans (Spalding, 1942; Tudge et al., 1998; Manjón-Cabeza and Evenness, 2000). For example, spermatophores of the crab species $G$. cruentata are simple, oval or spherical, and are enveloped by an acellular PAS-positive polysaccharide-rich film. Spermatophores of $C$. maenas are simple and resemble spherical capsules of uniform thickness with no particular external irregularities (Spalding, 1942). According to Mouchet (1931), the average spermatophore of $P$. marmoratus varies in size and sphericalness. In a study involving the species $S$. serrata, Uma and Subramoniam (1979) described the spermatophores as simple and mostly oval but occasionally triangular or spherical. The latter coincided with our observations of the spermatophores of G. cruentata.

Uma and Subramoniam (1979) described spermatophores as having two PAS-positive layers-the inner one, involved in spermatophore production, reacting more intensly to staining. Similarly, El-Sherief (1991) reported observing two layers in the wall of spermatophores of $P$. pelagicus, and Johnson (1980) found spermatophores to be surrounded by PAS and Alcian Blue-positive secretion. Beninger et al. (1988) reported a homogeneous and acellular film enveloping the spermatophores. Cronin (1947) found that the two fluids secreted by the anterior part of the vas deferens which played an important role in determining the mass of the spermatozoa and in forming the spherical spermatophores. These findings were later confirmed by Hinsch and Mcknight (1988) who emphasized that spermatophore formation and seminal fluid production were concomitant in this region. However, present findings for G. cruentata did not support this: one of the secretions found in the vas deferens of this species originated in the intermediary region of the testis. Sainte-Marie and Sainte-Marie (1999) found that the wall of spermatophores protected encapsulated sexual cells against substances present in the spermatheca that would otherwise be capable of inducing their complete development. Two amorphous substances observed were related to the presence of both mature and immature spermatids in the spermatophore.

\section{RESUMO}

Caranguejos são um importante recurso econômico para a população litorânea e o conhecimento dos aspectos reprodutivos fornecem base para o manejo das espécies. O presente estudo descreve a estrutura do testículo e do vaso deferente do caranguejo Goniopsis cruentata, e discute aspectos relacionados à formação do espermatofóro. O testículo é um órgão pareado, em forma de $\mathrm{H}$, situado logo abaixo da carapaça dorsal, enquanto o vaso deferente é bilateral e está localizado abaixo do coração. O testículo e o vaso deferente foram fixados em solução Bouin fria e submetidos à rotina histológica. A microscopia de luz revelou que o testículo é dividido em três regiões: anterior, que contém a zona germinativa; médio, onde estão localizados os ductos coletores; e posterior. $\mathrm{O}$ vaso deferente, contínuo com o testículo, é dividido em duas regiões: a primeira correspondendo às expansões e a segunda formada por um epitélio cúbico, fibras colágenas, camada circular de células musculares e glândula androgênica. Spermatophores were observed in both vas deferens regions, sugerindo sua participação na maturação dos espermatozóides, tornando o macho apto funcionalmente para a fecundação.

\section{REFERENCES}

Bauchau, A. (1966), La vie des crabes. Paris: Éditions Paul Lechevalier.

Benhalima, K. and Motiyasu, M. (2000), Structure and function of the posterior vas deferens of the snow crab, Chionoecetes opilio (Brachyura, Majidae). Invert. Reprod. Develop., 37 : (1), 11-23.

Beninger, P. G.; Elner, R. W.; Foyle, T. P. and Odense, P. H. (1988), Fuctional anatomy of the male reproductive system and the female spermatheca in the snow crab Chionoecetes opilio (O. Fabricius) (Decapoda: Majidae) and the hypothesis for fertilization. J. Crust. Biol., 8 : (3), 322-332.

Binford, R. (1913), The germ-cells and the process of fertilization in the crab, Menippe mercenaria. $J$. Morphol., 24 : (2), 147-201.

Burton, T. E. (1995), The spermatid pathway and associated reproductive structures of squat lobster Thenus orientalis (Lund, 1793). Invert. Reprod. Develop., 28 : (1), 53-61.

Cronin, L. E. (1947), Anatomy and histology of the male reproductive system of the Callinectes sapidus, Rathbun. J. Morphol., 81 : (2), 209-239. 
El-Sherief, S. S. (1991), Fine structure of the sper and spermatophores of Portunus pelagicus (L.) (Decapoda, Brachyura). Crustaceana, 61 : (3), 171179.

Hinsch, G. W. and Mcnight, C. E. (1988), The vas deferens of spanish lobster, Scyllarus chacei. Int. J. Invert. Reprod. Develop., 13, 267-280.

Hinsch, G. W. and Walker, M. H. (1974), The vas deferens of the spider crab, Libinia emarginata. $J$. Morphol., 143, 1-19.

Johnson, P. T. (1980), Histology of the blue crab Callinectes sapidus: A model for Decapoda. New York: Praeger Publishers.

Junqueira, L. C. and Junqueira, L. M. M. S. (1983), Técnicas básicas de Citologia e Histologia. São Paulo: Livraria e Editora Santos.

Krol, R. M.; Hawkins, W. E. and Overstreet, R. M. (1992), Reproductive Components. In: Harrisson, F. W. and Humes, A. G.: Microscopic Anatomy of Invertebrates. v. 10: Decapod Crustacea. Wiley-Liss, Inc.

Leite, M. M. L. (2002), Estudo morfológico do sistema reprodutor masculino do caranguejo-uçá Ucides cordatus Linnaeus, 1763 (Crustacea: Decapoda: Ocypodidae). 66 ff. Monografia, Universidade Federal do Ceará, Brasil.

Lima. A. V. P. (1995), Estudo do Sistema Reprodutivo de machos da Lagosta verde Panulirus laevicauda (LATREILLE, 1817) (DECAPODA: PALINURIDAE). 200 ff. Dissertação, Universidade Federal da Paraíba, Brasil.

Manjón-Cabeza, M. E. and Raso, J. E. G. (2000), Morphological reproductive aspects of males of Diogenes pugilator (Roux, 1829) (Crustacea, Decapoda, Anomura) from southern Spain. Sarsia, 85, 195-202.

Mouchet, S. (1931), Spermatophores des crustacés decápodes anomures et brachyoures et castration parasitaire chez quelques pagures. 199 ff. Tese, Faculdade de Ciências de Paris, France.

Pearse, A. G. E. (1960), Histochemistry theoretical and applied. London: Jet. Churchill. v. 2.

Ruppert, E. E. and Barnes, R. D. (1994), Invertebrate Zoology. $6^{\text {th }}$ ed.

Ryan, E. P. (1967), Structure and function of system of the crab Portunus sanguinolentus (Herbst) (BRACHYURA: PORTUNIDAE). The male system. In: Symposium on Crustacea of the Marine Biological Association, India. Proceedings... India. pp. 506-521.
Sainte-Marie, G. and Sainte-Marie, B. (1999), Reproductive products in the adult snow crab (Chionoecetes opilio). I. Observations ons spermatogenesis and spermathophore formation in the vas deferens. Can. J. Zool., 77, 440-450.

Spalding, J. F. (1942), The nature and formation of the spermatophore and sperm plug in crab, Carcinus maenas. Quat. J. Microsc. Science, 83, 399-422.

Talbot, P. and Summers, R. G. (1978), The structure of sperm from Panulirus, the spiny lobster, with special regard to the acrossome. J. Ultrast. Res., 64, 341-351.

Tolosa, E. M. C.; Rodrigues, C. J.; Behmer, O. A. and Freitas-Neto, A. G. (2003), Manual de Técnicas para Histologia Normal e Patológica.

Tudge, C. C.; Jamieson, B. G. M.; Sandberg, L. and Erséus, C. (1998), Ultrastruture of the mature spermatozoon of the king crab Lithodes maja (Lithodidae, Anomura, Decapoda): further confirmation of a lithodid-pagurid relationship. Invert. Biol., 117 : (1), 57-66.

Uma, K. and Subramoniam, T. (1979), Histochemical characteristics of spermatophore layers of Scylla serrata (Forskal) (Decapoda: Portunidae). Int. J. Invert. Reprod., 1, 31-40.
Received: May 20, 2004; Revised: January 13, 2005; Accepted: January 09, 2006. 